\title{
Colloquy
}

\section{MULTISCALE HOME: Shifting Landscapes and Living-in-Movement in Haiti}

\author{
FEDERICO NEIBURG \\ Universidade Federal do Rio de Janeiro \\ (D) https:/ / orcid.org/0000-0002-9917-8604
}

I met Daphney in the tent where she had found shelter, next to the site where she was born and had lived on Macajou Street, in downtown Port-au-Prince.

It was May 2010. A couple of months earlier, on January 12, a massive earthquake that struck the city had reduced the residences of hundreds of thousands of people to rubble. Daphney and her son Fritznel spent almost two days immobilized under the debris, separated by the remains of collapsed walls yet hearing each other's voices, until relatives and neighbors managed to open a hole to pass them water and then finally rescue them.

I have known Daphney since 2007, when I arrived in Haiti to start a collaborative study of its dynamic urban economy and to lead a multinational ethnographic research and training program for young scholars (Neiburg 2019). Over the years, I visited Daphney's lakou on Macajou Street many times. There are still some urban lakou like hers in Port-au-Prince: sets of houses inhabited by kin-related people, connected by a yard or central corridor and with a ritual space around a peristil, where ceremonies are held for the spirits (lwa) and the graves of kin are located. ${ }^{1}$ 
Macajou Street was now populated by dozens of tents like Daphney's. Sanitary conditions had fast deteriorated, and a cholera outbreak worsened the situation, bringing the bacterial specter of death into all intimate spaces. The immensity of the tragedy — an "acute-on-chronic event," in Paul Farmer's (2011, 21) rendering - evinced ways of dwelling and connecting persons and houses with deep historical trajectories (in the wake of the plantation and marronage), which would be reanimated in calamities to come, such as today's COVID-19 pandemic. This oikography essay is located at the crossroads of two intellectual traditions: one has shown the vital relational character of Haitian houses (such as the concept of "configuration of houses" in Marcelin [1996]), while the other has emphasized the generativity of Haitian mobility (Anglade 1982). Building on these important bodies of work, I am interested in the intrinsic relationships between house-ing practices, mobility, and scales - and the centrality of these linkages to the experience of personhood and belonging. To Daphney and my Haitian interlocutors and friends, mobility involves geographic and temporal scales constitutive of their personal and collective trajectories and of the house as a physical, moral, and affective territory. As in Eugênia Motta's (2021, this issue) and Thiago da Costa Oliveira's and Carlos Fausto's (2021, this issue) oikographies, here, too, the house constitutes at once a place (or several places) and a conceptual field, a landscape of sorts where personhood and houses are built in motion.

As Macajou Street had become quite a dangerous place, Daphney was relieved to have found a refuge for her child in another tent on the grounds of an NGO for which she had occasionally worked. What tormented her most, she told me, was her immobilization. The catastrophe had interrupted her movements between Port-au-Prince and Miami, a circuit she traveled to engage in "small commerce" ( $t i$ komès) of clothing and beauty products. She is also an artist, and constant visits to the United States nourished Daphney's hope to one day record a hip hop hit and become a professional musician. This aspiration was Daphney's own chache lavi myo, a way of "seeking a better life" for herself and her son. Now, trapped in the street, she felt like the living dead, a zombie (tankou yon zonbi), she said:

My house [kay mwen] collapsed, but here [pointing to the tent] is now my base [baz mwen], Pako [the location where her young son was living] is my base, this entire zone [zon] is my base; that lakou is my house, everything there was made by my grandfather and great-grandfather, but living like this now, trapped, I feel like I’m dying [konsa lòk mwen santi m mouri]. 
The earthquake dramatically affected relations between persons and houses. At least 250,000 people died, while thousands more were mutilated and injured, leaving an immeasurable trail of orphaned children, homeless families, and devastated infrastructure. It is estimated that more than 40 percent of the houses in some central districts of Port-au-Prince were destroyed or seriously damaged. At least 300,000 people fled the city, most of them heading to the countryside. Many left for the Dominican Republic and other destinations that compose Haiti's diasporic geography: traditionally North America and France, and now also South America. ${ }^{2}$

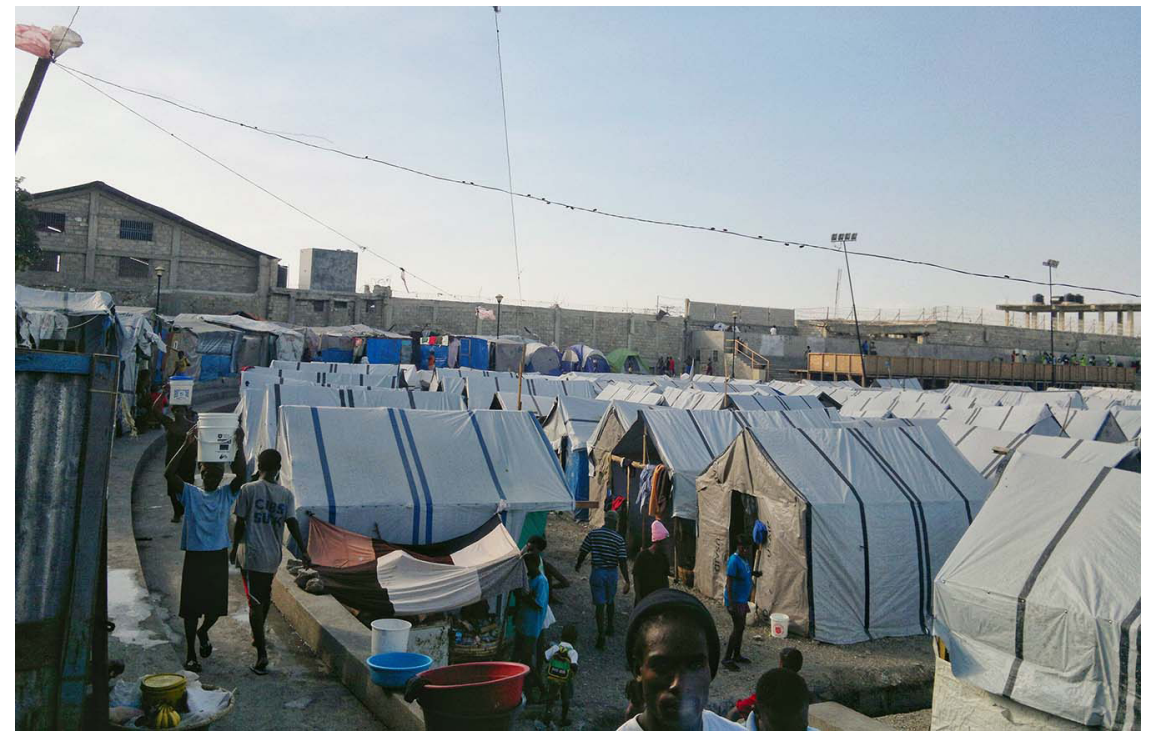

Figure 1. Refugee camp after the earthquake. Bel Air, Port-au-Prince, May 2010.

Photo by Federico Neiburg.

In the Caribbean landscapes, mobility and immobility have always coexisted intensely. Plantation and post-plantation worlds have been inhabited by enslaved and escaped people (mawon people). In Haiti, this tension acquired even more intense modulations, permeated by the permanent sense of crisis (Beckett 2019) and extreme poverty that impels movement (Dalmaso 2019; Bulamah 2020; Joseph 2020; Neiburg and Joseph 2021), making the act of "taking to the road" (prann wout a) (Montinard 2020) a synonym of life and transformation, as Daphney herself noted: immobility signals the imminence of death. A popular proverb says: kote ki gen grangou, kabrit pa mouri nan kòd, "where there is hunger, no goats die tethered to their ropes.” Being stuck, prevented from moving, is synonymous with an ab- 
sence of life, like in the extreme cases of people forced into slavery or those killed by magic. As I learned from my interlocutors in Haiti and in the Haitian diaspora, movement stabilizes relations between those at home and, even at a distance, supports bonds with kin and ancestors, between those residents in a place and those moving within and across national borders. Movement is relationally productive, and relationality is the condition of possibility for movement. The home is inhabited by people in motion, and mobile people inhabit many houses. Even children grow up in relations with several houses, accompanying their parents or spending time with others while on the move. House-ing happens in and through multiple houses across scales.

Daphney's statement echoes a theme that, time and again, emerged in my ethnographic encounters, before and after the earthquake. The house (kay) makes for a temporal and spatial multiscale universe, a unit that integrates and dissolves into others, always contextually: the eritaj (heritage), which connects the house to its various pasts and ancestral figures (in Daphney's case: her grandfather and great-grandfather), and the configuration of diverse houses that forms the lakou, the zon, the vwazinaj (neighborhood), and the baz, a concept that designates multiple spaces, from the materiality of the house itself to a street corner or spot where people feel emotionally and materially safe, at home, in the company of those close to them. Louis Herns Marcelin's (2012) observation about the concept of family (fanmi) suits the imaginary of the house to which the family is intrinsically associated: spaces of closeness and relatedness, among neighbors, friends, members of the same village or city, or even a common humanity. That is why Daphney referred to the space she inhabited after the earthquake as her baz, a place of life amid the tragedy.

When I moved to Princeton, New Jersey, for a sabbatical in the fall of 2019, I met Willian, one of Daphney's brothers, who was living in the same lakou on Macajou Street at the time of the earthquake and who had moved to the United States a few years later. I was happy to hear that Daphney and her son were safe and doing well — she in Boston and Fritznel in Jeremie, in the extended home in southwestern Haiti. Willian and I met regularly to catch up until we had to quarantine because of the COVID-19 pandemic. We continued to communicate through WhatsApp, a device constitutive of Haitians' mobile relatedness long before the confinement. Mobility also formed part of my own experience, distributed not only between the United States and Brazil but also Argentina, Belgium, and Mexico, where I have loved ones and homes. Willian knew me well, which is why he used to refer to me as a moun dyaspora (a diaspora man), like himself. 
While we accompanied each other at a distance during this acute uncertainty, I managed to feel the great suffering that immobility was causing Willian. The Uber service he was providing stopped, and this affected not only the livelihood of his home near Newark, where he lived with his Haitian wife, but also the other houses to which he regularly sent remittances: the houses of his lakou on Macajou Street and in Jeremie where he had grown up in the care of one of his aunts and where his beloved nephew now lived.

Willian, like other Haitian friends with whom I have maintained communication during the pandemic, experienced the shadow of death associated with immobility, not only in the material aspect of money and remittances but also in the indefinite suspension of flights that kept him from his loved ones. Yet he insisted on "waiting for better times to search for a better life" (retann yon bon moman pou chache lavi miyò). Digital communication partially mitigated his suffering, allowing him to be near from afar, injecting life into confinement, reinserting him and his house in a multiscale vital landscape, connecting with close friends and family distributed in space (in several houses) and in time (with his ancestors, always present at the lakou). Macajou Street's lakou came back into view one Saturday, in April 2020, when a mobile phone near the peristyle allowed Willian in his Newark house, Daphney in her Boston house, me in my Princeton house, and "our people" in Port-au-Prince to be together, listening to the drums, looking at dances, sharing time and affection, cultivating our virtual and desired human presence, linking our homes and lives.

\begin{abstract}
In January 2010, a catastrophic earthquake ravaged Haiti. In areas such as Portau-Prince, the tragedy was compounded by an ensuing cholera outbreak. Here, conditions of prolonged crisis illuminate people's resilient house-ing responses at the intersection of two dynamics: the vital relational character of Haitian houses and the necessity of mobility for producing new life. Rooted in the Haitian post-plantation world, the house (kay) does not constitute a bounded space but is rather realized conceptually and materially at diverse scales: people belong to many interdependent houses and houses belong to many interrelated people, sutured across space and time and between the living and the dead. In the wake of the 2010 disaster, and now amid the COVID-19 pandemic, new challenges and opportunities have arisen for diasporic families as they craft ways to enact and secure multiscale forms of livelihood. [multiscale housing; mobility and diaspora; natural disasters; living-in-movement; Haiti and the Caribbean]
\end{abstract}




\section{REZIME}

Nan mwa janvye ane 2010, yon tranbleman tè vyolan te frape Ayiti. Nan kèlke zòn tankou Pòtoprens, kapital la, trajedi a te vin agrave akòz yon epidemi kolera. Kriz pwolonje sa a montre detèminasyon moun yo nan yon entèseksyon ki gen ladan 1 de dinamik: 1) youn ki montre karaktè relasyonèl ak vital kay ayisien yo; 2) lòt la ki konsantre 1 sou mouvman pou bay lavi a sans. Kay, ki gen rasin li nan mond apre peryòd plantasyon an, li pa sèlman yon espas ki separe ak yon fwontyè fizik, men konseptyèlman e materyèlman nan plizyè echèl: moun yo fè pati plizyè kay entèdepandan, epi tou kay yo apateni ak plizyè moun ki entèrelasyone, gras a lyen ke yo genyen ki limite nan espas ak nan tan, ant moun vivan yo ak sila ki mouri yo. Nan dezas 2010 la ak nan moman pandemi Kovid-19 la, fanmi yo gen nouvo defi ak opòtinite pandan y ap kreye nouvo mwayen nan plizyè dimansyon pou lavi ka kontinie. [kay an plizyè echèl; lavi an mouveman; dezas natirèl; Ayiti ak Karayib la]

\section{RESUMEN}

En enero de 2010 un violento terremoto devastó Haití. En zonas como la capital, Port-au-Prince, la tragedia se vio agravada por una epidemia de cólera. La crisis prolongada ilumina la resiliencia de las personas en la intersección de dos dinámicas: una, que señala el carácter relacional y vital de los hogares haitianos y, otra, que tematiza la movilidad para producir vida. Enraizada en el mundo de la post-plantación, la casa (kay) no es sólo un espacio delimitado por fronteras físicas, sino que se realiza conceptual y materialmente en escalas múltiples: las personas pertenecen a varias casas interdependientes y las casas pertenecen a varias personas interrelacionadas, en vínculos suturados a través del espacio y del tiempo, entre los vivos y los muertos. Entre la catástrofe de 2010 y la pandemia de Covid-19 surgen nuevos desafíos y oportunidades para las familias diaspóricas que encuentran nuevas formas de asegurar la vida en múltiples escalas. [casas en múltiples escalas; movilidad y diáspora; catástrofes naturales; vida en movimiento; Haití y Caribe]

\section{RESUMO}

Em janeiro de 2010 um violento terremoto devastou o Haiti. Em áreas como a capital, Port-au-Prince, a tragédia foi agravada por uma epidemia de cólera. A crise prolongada ilumina a resiliência das pessoas na interseção de duas dinâmicas: a que aponta o caráter relacional e vital das casas haitianas e a que tematiza a mobilidade para produzir vida. Enraizada no mundo pós-plantação, a casa (kay) não é só um espaço limitado por fronteiras físicas, mas realizada conceitual e materialmente em diversas escalas: as pessoas pertencem a muitas casas interdependentes e as casas pertencem a muitas pessoas inter-relacionadas, através de vínculos suturados no espaço e no tempo e entre vivos e mortos. Na esteira do desastre de 2010, e em meio à pandemia de Covid-19, novos desafios e oportunidades surgem para as famílias diaspóricas à medida que criam novas maneiras de assegurar formas vitais em múl- 
tiplas escalas. [moradia em múltiplas escalas; mobilidade e diáspora; desastres naturais; vida em movimento; Haiti e Caribe]

\section{NOTES}

Acknowledgments Thanks to Flavia Dalmaso for the permanent dialogue on these issues, and to Handerson Joseph and Rodrigo C. Bulamah for their generous critical readings.

1. Lakou refers to the traditional residential unit of rural Haiti. Many in downtown Portau-Prince, where Daphney's lakou is located, are migrants from the rural hinterland who settled there in the 1970s. Subsequent migratory waves, especially of people fleeing violence, have overwhelmed the city, further stressing property regimes and impacting inheritance and kinship ties (Beckett 2019; Kivland 2020).

2. About two million people live in Port-au-Prince, ten million in Haiti as a whole, and at least four million in the diaspora.

\section{REFERENCES}

Anglade, Georges

1982 Espace et liberté en Haïti. Montréal: ERCE.

Beckett, Greg

2019 There Is No More Haiti: Between Life and Death in Port-au-Prince. Berkeley: University of California Press.

Bulamah, Rodrigo Charafeddine

2020 "Times and Metaphors of Pandemics." Social Anthropology 28, no. 2: 232-33. https://doi.org/10.1111/1469-8676.12866.

Costa Oliveira, Thiago da, and Carlos Fausto

2021 “Amazonian House-ing: A Visual Anthropology Essay." Cultural Anthropology 36, no. 4: 580-88. https://doi.org/10.14506/ca36.4.06.

Dalmaso, Flavia

2019 “Família.” In Conversas etnográficas haitianas, edited by Federico Neiburg, 53-80.

Farmer, Paul Rio de Janeiro: Papéis Selvagens.

2011 Haiti after the Earthquake. New York: Public Affairs.

Joseph, Handerson

2020 "Maisons diasporas et maisons locales: Mobilités haïtiennes et réseaux transnationaux." Etnográfica 24, no. 3: 749-74. https://doi.org/10.4000/

Kivland, Chelsey L. etnografica.9566.

2020 Street Sovereigns: Young Men and the Makeshift State in Urban Haiti. Ithaca: Cornell University Press.

Marcelin, Louis Herns

1996 "A invenção da família afro-americana: Família, parentesco e domesticidade entre os negros do recôncavo da Bahia, Brasil.” PhD diss., Museu Nacional, Universidade Federal do Rio de Janeiro.

2012 "In the Name of the Nation: Blood Symbolism and the Political Habitus of Violence in Haiti." American Anthropologist 114, no. 2: 253-66. https://doi.org/10.1111/ j.1548-1433.2012.01423.x.

Montinard, Mélanie

2020 "Pran wout la: Expériences et dynamiques de la mobilité haïtienne." Vibrant: Brazilian Motta, Eugênia Virtual Anthropology 17: 1-33. https://doi.org/10.1590/1809-43412020v17d503.

2021 "The Dying Home: 'Bad Deaths' and Spatial Inscriptions of Mourning in a Favela." Cultural Anthropology 36, no. 4: 556-62. https://doi.org/10.14506/ca36.4.03. 
Neiburg, Federico, and Handerson Joseph

2021 "Searching for Life in Times of Pandemic." In Pandemic Exposures: Economy and Society in the Time of Coronavirus, edited by Didier Fassin and Marion Fourcade, 387-410. Chicago: Hau Books

Neiburg, Federico, ed.

2019 Conversas etnográficas haitianas. Rio de Janeiro: Papéis Selvagens. 